\title{
Initiation of Rice Sheath Blight Epidemics and Effect of Application Timing of Azoxystrobin on Disease Incidence, Severity, Yield, and Milling Quality
}

\author{
D. E. Groth, Professor, and J. A. Bond, Assistant Professor, Rice Research Station, Louisiana Agricultural Experi- \\ ment Station, Louisiana State University Agricultural Center, 1373 Caffey Road, Rayne, LA 70578
}

\begin{abstract}
Groth, D. E., and Bond, J. A. 2006. Initiation of rice sheath blight epidemics and effect of application timing of azoxystrobin on disease incidence, severity, yield, and milling quality. Plant Dis. 90:1073-1076.

The lack of sheath blight-resistant cultivars requires rice (Oryza sativa) farmers to use fungicides to control the disease and avoid significant reductions in grain and milling yield. Sheath blight (Rhizoctonia solani) epidemics can begin over a period of weeks during the growing season, and initiation date can have significant effects on crop damage and fungicide application timing. Studies were conducted to determine how different epidemic initiation and azoxystrobin application timings affect disease development, rice yield, and milling quality. Sheath blight epidemics in field plots were initiated by inoculation at the green ring (GR), panicle differentiation (PD), early boot (EB), and late boot (LB) growth stages in 2002 to 2004. Azoxystrobin was applied to the foliage at $0.17 \mathrm{~kg}$ a.i. ha ${ }^{-1}$ at 7 days after PD (PD+7), midboot (B), and $50 \%$ heading $(\mathrm{H})$. Inoculation significantly increased sheath blight severity and incidence and reduced yield and milling quality. There were no significant effects of inoculation timing at the GR, PD, EB, and LB growth stages. Fungicide applications made between PD+7 and $\mathrm{H}$ reduced sheath blight severity and incidence, resulting in higher yield and head rice milling yield compared with inoculated but nonsprayed plots.
\end{abstract}

Additional keywords: yield loss

Sheath blight, caused by Rhizoctonia solani Kühn AG1-1A (teleomorph: Thanatephorus cucumeris (A.B. Frank) Donk. [19]) is the most important rice (Oryza sativa L.) disease in the southern United States $(15,20)$. Under conditions favorable for disease development, grain yield losses ranging from 1 to $25 \%$ have been reported $(6,17,18)$. Disease severity is dependent on amount of inoculum, crop growth stage at infection, environmental conditions, cultivar resistance, and cultural management $(4,11,21,22)$. High sheath blight intensity in the U.S. Gulf Coast growing region has been attributed to cultural practices used in modern rice production, including more susceptible semidwarf long-grain cultivars, high nitrogen fertilization rates, rotation with the alternative host soybean (Glycine max (L). Merr.) (20), and high plant populations $(7,10)$. Losses occur due to reductions in grain yield, grain quality, and lodging in the first (main) crop, and reductions in plant population in the second (ratoon) crop $(9,17)$.

Corresponding author: D. E. Groth

E-mail: dgroth@agcenter.lsu.edu

Accepted for publication 3 April 2006.

DOI: 10.1094/PD-90-1073

(C) 2006 The American Phytopathological Society
Azoxystrobin, trifloxystrobin, and flutolanil are currently labeled in the United States for sheath blight control in rice (5). While these fungicides are more effective than propiconazole and some other fungicides no longer used for sheath blight control in the United States, including benomyl and iprodione $(8,9,12,14)$, they can be expensive and ineffective if applied at the wrong application timing. Benefits from the currently used fungicides include reduced disease development, possible reduction of inoculum, and increased grain and milling yields, a key component in rice grain quality and price (5). Azoxystrobin is the most commonly used rice fungicide in the southern United States (6). Information is limited on the optimum fungicide application timing when sheath blight starts to develop early or late in the growing season. Preliminary studies suggest that the optimum application timing for azoxystrobin to achieve effective sheath blight control changes in response to when the sheath blight epidemic begins during the growing season (9). Typical fungicide application timing for sheath blight is during the boot growth stage. However, azoxystrobin also controls blast when applied at rice heading. Consequently, a trend has developed toward later application timings for azoxystrobin in an attempt to control both blast and sheath blight with a single application. The objectives of this study were to determine the impact of different sheath blight epidemic initiation timings on rice grain and milling yields and to determine the proper application timing for azoxystrobin relative to start of sheath blight.

\section{MATERIALS AND METHODS}

Experiments were conducted at the LSU Agricultural Center Rice Research Station in Crowley, LA. The sheath blight susceptible cultivar Cocodrie (16) was drillseeded on 18, 25, and 23 March in 2002, 2003 , and 2004, respectively, at $136 \mathrm{~kg} \mathrm{ha}^{-1}$. Plots were $1.2 \times 4.9 \mathrm{~m}$ and consisted of seven rows at $18-\mathrm{cm}$ spacing. Soil type was a Crowley silt loam ( $\mathrm{pH}$ 6.0, clay $12 \%$, silt $71 \%$, sand $17 \%$, CEC $9.4 / \mathrm{kg}$ ). Fertilizer (N-P-K) was incorporated 1 day before planting at the rate of $24-67-67 \mathrm{~kg}$ $\mathrm{ha}^{-1}$. Agronomic, weed, and insect management practices followed current standard recommendations (1). Nitrogen was applied prior to flooding at $133 \mathrm{~kg} \mathrm{~N} \mathrm{ha}^{-1}$ as urea at the three- to four-leaf stage and after flooding at $51 \mathrm{~kg} \mathrm{~N} \mathrm{ha}^{-1}$ as urea at the beginning of stem internode elongation.

Inoculation. Plots were inoculated at green ring (GR, panicle initiation), panicle differentiation ( $\mathrm{PD}$, panicle $0.2 \mathrm{~mm}$ in length), early boot (EB, 1- to 3-cm panicle in the boot), or late boot (LB, panicle fully formed but not emerging) growth stages with a virulent isolate of $R$. solani (LR172). LR172 was originally isolated from a naturally infected rice plant (cv. Lebonnet) in Louisiana by M. C. Rush in 1972. Inoculum was produced on a moist, autoclaved rice grain/rice hull mixture (1:2 $\mathrm{vol} / \mathrm{vol}$ ) incubated in the dark for 12 to 14 days at $30^{\circ} \mathrm{C}$. The grain-hull inoculum was broken into small (3- to 7-mm diameter) particles, consisting of several rice grains held together by fungal mycelia. Approximately $100 \mathrm{ml}\left(17 \mathrm{ml} \mathrm{m}^{-2}\right)$ were distributed evenly over each plot by hand at the appropriate growth stages except for noninoculated controls. Inoculation dates were: GR = 16 May 2002, 14 May 2003, and 1 June 2004; PD = 22 May 2002, 23 May 2003, and 10 June 2004; EB = 3 June 2002, 10 June 2003, and 17 June 2004; and LB = 11 June 2002, 20 June 2003, and 23 June 2004.

Fungicide treatments. Azoxystrobin (Quadris 2.08 SC, Syngenta, Raleigh, NC) was applied at the most commonly used rate of $0.17 \mathrm{~kg}$ a.i. ha ${ }^{-1}, 7$ days after PD $(\mathrm{PD}+7)$, boot $(\mathrm{B}, 5-$ to $10-\mathrm{cm}$ panicle in the boot), and heading $(\mathrm{H}, 50$ to $70 \%$ of heads emerging from the boot) rice stages. 
Treatments were applied at a delivery rate of 140 liters ha ${ }^{-1}$ with a $\mathrm{CO}_{2}$-pressurized backpack sprayer. Dates of applications were: PD+7 = 29 May 2002, 3 June 2003, and 15 June 2004; B = 8 June 2002, 16 June 2003, and 20 June 2004; and $\mathrm{H}=17$ June 2002, 24 June 2003, and 28 June 2004. Nonsprayed checks were included.

Disease assessments and yield determination. Plots were evaluated for sheath blight development approximately 1 week before grain maturity and assigned severity ratings using a semilinear scale $(9,12,15,23)$ on 22,17 , and 20 July 2002 , 2003, and 2004, respectively. At the same time, 25 tillers at four locations in the center four rows of each plot were examined for symptoms, and percent symptomatic stems were calculated.

On 25 July, 30 July, and 2 August 2002, 2003, and 2004, respectively, the center four rows of each plot were harvested with a small-plot combine. Grain yield and moisture were determined, and rice yields were adjusted to $12 \mathrm{~g} \mathrm{~kg}^{-1}$ moisture content. A 125-g grain subsample was collected from each harvest sample for determining milling percentages of whole (unbroken kernels) and total rice (broken and whole grains). The subsample was hulled with a McGill Sheller, setting 19 (RAPSCO, Brookshire, TX), to remove the lemma and palea. The resulting brown rice was then processed in a McGill Miller (RAPSCO) for $30 \mathrm{~s}$ to remove the bran layers and part of the embryo. The milled sample was weighed to determine total milled yield percentages and then placed on a Grainman grain separator (Grain Machinery Manufacturing Corporation, Miami, FL) with no. 10 and no. 11 plates to remove broken kernels. Whole kernels were then weighed to determine whole milling or head rice. Milling yield percentages were calculated as [(weight/125)*100]. Head rice milling yield quality was considered commercially acceptable if it met the standard industry values for rice of $55 \%$ head rice and $70 \%$ total rice.

Data analysis. Treatments were replicated four times in a randomized complete block design with a factorial arrangement of five inoculation and four fungicide timings. Data were analyzed using the Mixed Procedure (SAS Institute, Cary, NC). Year was used as a random-effect parameter testing all possible interactions of inoculation and fungicide application timings. Years, replications (nested within years), and all possible interactions containing these effects were considered random effects; all other variables (inoculation and fungicide application timings) were considered fixed effects. Considering year as an environmental or random effect permits inferences about treatments to be made over a range of environments (3). A similar statistical approach has been successfully used by other researchers $(2,24)$. Type III Statistics were used to test all possible fixed effects or interactions between the fixed effects, and least square means at $P \leq$ 0.05 were used for mean separation.

\section{RESULTS}

Disease development and effect of inoculation and azoxystrobin timing. Severe sheath blight developed uniformly each year, averaging over $80 \%$ incidence (percent infected tillers) and a severity of 8.0 ( 0 to 9 scale where 9 is most severe) in the inoculated nonsprayed plots. In plots inoculated with $R$. solani, initial symptoms developed on 10 to $20 \%$ of the tillers within 7 to 10 days of inoculation, and these incidence levels were within treatment thresholds for sheath blight $(1,11)$. Noninoculated plots were relatively disease-free with only 6 to $13 \%$ infected tillers at the end of the season. Percent tillers affected by sheath blight ranged from $6 \%$ in the noninoculated B-sprayed treatment to $90 \%$ in the PD-inoculated nonsprayed check (Table 1). Noninoculated treatments had significantly less tillers infected than inoculated nonsprayed treatments, but inoculation timing did not have a significant effect on incidence level (Table 1). All fungicide timings had significantly lower percent infected tillers than the nonsprayed timing. Except for the LB inoculation $\mathrm{PD}+7$ versus $\mathrm{B}$ and $\mathrm{H}$ fungicide applications, there were no differences between fungicide timings at individual inoculation timings. Comparing treatments with different fungicide timings at $\mathrm{PD}+7, \mathrm{~B}$, and $\mathrm{H}$ revealed average incidence numerically lower at the B application, but not significantly so.

Sheath blight severity in naturally infected plots was very low, averaging 4.6 ( 0 to 9 scale) in the noninoculated nonsprayed check (Table 1). Severe sheath blight, averaging 8.1 ( 0 to 9 scale), developed in the inoculated nonsprayed checks. Inoculation timing had no effect on final sheath blight severity (Table 1). All fungicide treatments had significantly lower sheath blight severity than the inoculated nonsprayed checks. Comparing fungicide treatments at $\mathrm{PD}+7, \mathrm{~B}$, and $\mathrm{H}$, sheath blight severity tended to be lower at the $\mathrm{B}$ and $\mathrm{H}$ growth stages for the EB and LB

Table 1. Effects of inoculation and azoxystrobin application timing on sheath blight incidence and severity, yield, and milling quality ${ }^{\mathrm{w}}$

\begin{tabular}{|c|c|c|c|c|c|c|}
\hline \multirow{2}{*}{$\begin{array}{l}\text { Inoculation }{ }^{x} \text { timing } \\
\text { (growth stage) }\end{array}$} & \multirow{2}{*}{$\begin{array}{l}\text { Fungicide }{ }^{x} \text { timing } \\
(0.17 \text { kg a.i. ha-1) }\end{array}$} & \multirow{2}{*}{$\begin{array}{c}\text { Infected }{ }^{\mathrm{y}} \text { tillers } \\
(\%)\end{array}$} & \multirow{2}{*}{$\begin{array}{l}\text { Sheath blight } \\
\text { severity }\end{array}$} & \multirow{2}{*}{$\begin{array}{l}\text { Grain yield } \\
\left(\mathrm{kg} \mathrm{ha}^{-1}\right)\end{array}$} & \multicolumn{2}{|c|}{ Milling quality } \\
\hline & & & & & Head rice $(\%)$ & Total (\%) \\
\hline Noninoculated & Nonsprayed & $13 \mathrm{efg}$ & $4.6 \mathrm{c}-\mathrm{f}$ & $9,347 \mathrm{a}-\mathrm{e}$ & $60.6 \mathrm{bcd}$ & $71.0 \mathrm{abc}$ \\
\hline Noninoculated & $\mathrm{PD}+7$ & $9 \mathrm{fg}$ & $4.0 \mathrm{ef}$ & $9,604 \mathrm{abc}$ & $61.1 \mathrm{abc}$ & $71.4 \mathrm{ab}$ \\
\hline Noninoculated & $\mathrm{B}$ & $6 \mathrm{~g}$ & 3.8 ef & $9,589 \mathrm{abc}$ & $61.3 \mathrm{abc}$ & $71.2 \mathrm{ab}$ \\
\hline Noninoculated & $\mathrm{H}$ & $10 \mathrm{fg}$ & $3.4 \mathrm{f}$ & $9,804 \mathrm{a}$ & $61.4 \mathrm{abc}$ & $71.9 \mathrm{a}$ \\
\hline GR & Nonsprayed & $85 a$ & $8.1 \mathrm{a}$ & $7,147 \mathrm{f}$ & $59.0 \mathrm{e}$ & $70.2 \mathrm{c}$ \\
\hline GR & $\mathrm{PD}+7$ & $39 \mathrm{~b}-\mathrm{f}$ & $5.9 \mathrm{bc}$ & $8,942 \mathrm{c}-\mathrm{e}$ & $61.4 \mathrm{abc}$ & $71.0 \mathrm{abc}$ \\
\hline GR & $\mathrm{B}$ & $28 \mathrm{~b}-\mathrm{g}$ & $4.8 \mathrm{c}-\mathrm{f}$ & $9,305 \mathrm{a}-\mathrm{e}$ & $61.7 \mathrm{abc}$ & $71.3 \mathrm{ab}$ \\
\hline GR & $\mathrm{H}$ & $40 \mathrm{bcd}$ & $5.5 \mathrm{bcd}$ & $8,709 \mathrm{e}$ & $61.1 \mathrm{abc}$ & $70.8 \mathrm{bc}$ \\
\hline PD & Nonsprayed & $90 \mathrm{a}$ & $8.1 \mathrm{a}$ & $7,190 \mathrm{f}$ & $59.0 \mathrm{e}$ & $70.5 \mathrm{bc}$ \\
\hline PD & $\mathrm{PD}+7$ & $19 \mathrm{c}-\mathrm{g}$ & $4.7 \mathrm{c}-\mathrm{f}$ & 9,322 a-e & $60.8 \mathrm{a}-\mathrm{d}$ & $70.9 \mathrm{bc}$ \\
\hline PD & B & $15 \mathrm{~d}-\mathrm{g}$ & $4.3 \mathrm{def}$ & $9,721 \mathrm{a}$ & $61.1 \mathrm{abc}$ & $70.9 \mathrm{bc}$ \\
\hline PD & $\mathrm{H}$ & $43 \mathrm{bc}$ & $5.3 \mathrm{~b}-\mathrm{e}$ & 9,269 a-e & $60.7 \mathrm{a}-\mathrm{d}$ & $71.0 \mathrm{abc}$ \\
\hline EB & Nonsprayed & $83 \mathrm{a}$ & $8.0 \mathrm{a}$ & $7,376 \mathrm{f}$ & $59.4 \mathrm{de}$ & $70.4 \mathrm{bc}$ \\
\hline EB & $\mathrm{PD}+7$ & $33 \mathrm{c}-\mathrm{f}$ & $6.0 \mathrm{bc}$ & $9,002 \mathrm{~b}-\mathrm{e}$ & $61.7 \mathrm{abc}$ & $71.4 \mathrm{ab}$ \\
\hline $\mathrm{EB}$ & B & $11 \mathrm{fg}$ & $4.3 \mathrm{def}$ & 9,324 a-e & $62.3 \mathrm{a}$ & $71.8 \mathrm{a}$ \\
\hline EB & $\mathrm{H}$ & $28 \mathrm{~b}-\mathrm{g}$ & $4.7 \mathrm{c}-\mathrm{f}$ & $9,629 \mathrm{ab}$ & $60.8 \mathrm{a}-\mathrm{d}$ & $70.8 \mathrm{bc}$ \\
\hline LB & Nonsprayed & $84 \mathrm{a}^{\circ}$ & $8.1 \mathrm{a}$ & $7,524 \mathrm{f}$ & $60.1 \mathrm{cde}$ & $70.7 \mathrm{bc}$ \\
\hline LB & $\mathrm{PD}+7$ & $50 \mathrm{~b}$ & $6.3 \mathrm{~b}$ & 8,870 de & $61.7 \mathrm{abc}$ & $71.2 \mathrm{ab}$ \\
\hline LB & $\mathrm{B}$ & $16 \mathrm{~d}-\mathrm{g}$ & $4.3 \mathrm{def}$ & $9,483 \mathrm{a}-\mathrm{d}$ & $60.9 \mathrm{a}-\mathrm{d}$ & $71.1 \mathrm{ab}$ \\
\hline LB & $\mathrm{H}$ & $23 \mathrm{c}-\mathrm{g}$ & $4.3 \mathrm{ef}$ & $9,643 \mathrm{ab}$ & $61.3 \mathrm{abc}$ & $71.2 \mathrm{ab}$ \\
\hline
\end{tabular}

${ }^{w}$ Means are 3-year average of small-plot field tests conducted at the Rice Research Station, Crowley, LA. Years were 2002 to 2004.

${ }^{x}$ Timings used included GR (green ring or internode initiation), PD (panicle first identifiable or panicle 2 mm in size), PD+7 (7 days after PD), EB (5- to 10$\mathrm{cm}$ panicle in the boot), LB (late boot or panicle fully formed but not emerging), and heading (70 to $80 \%$ of panicles emerging).

${ }^{y}$ Percent tillers infected with sheath blight at approximately 1 week before harvest.

${ }^{\mathrm{z}}$ Sheath blight rated 1 week before harvest on a 0 to 9 scale where $0=$ no disease and $9=$ plants dead and collapsed. 
inoculation timings. There were no significant differences in sheath blight severity between the nonsprayed and sprayed noninoculated treatments.

Grain yield and quality. Grain yield in the noninoculated check averaged $2,037 \mathrm{~kg}$ $\mathrm{ha}^{-1}(22 \%)$ more than that in the inoculated checks (Table 1). Yield was as much as $2,657 \mathrm{~kg} \mathrm{ha}^{-1}$ higher between the best (noninoculated, $\mathrm{H}$ fungicide) and worst (GR inoculated, nonsprayed) treatments. Inoculation timing did not have any significant effect on grain yield, with all inoculated nonsprayed treatments having lower yields than noninoculated treatments (Table 1). All fungicide treatments increased yield over the corresponding nonsprayed checks (Table 1). Applications before or after inoculation were effective in increasing yields, but PD+7 yielded lower than the B application at the LB inoculation. There were no differences in yield between the nonsprayed and sprayed noninoculated treatments.

Head rice milling yield was commercially acceptable in all treatments. Inoculation did not have an effect on head rice milling yields. Fungicide treatments increased head rice milling yield over the inoculated nonsprayed check except in the EB $\mathrm{H}$ combination and at the LB inoculation timing (Table 1).

Total milling yield was commercially acceptable in all treatments. Inoculation timing in nonsprayed treatments did not have a significant effect on total milling yield, although total rice yield increased as inoculation was delayed. Only one fungicide treatment, the EB inoculation B application, significantly increased total rice milling yield.

\section{DISCUSSION}

Percent affected tillers and severity of sheath blight from natural inoculum were very low in these experiments, but sheath blight caused significant yield and milling yield reductions to rice plants at all inoculation timings when not sprayed, compared with rice in noninoculated plots. The difference between the lightly diseased, noninoculated control and the inoculated, nonsprayed controls indicated that sheath blight caused a $22 \%$ grain yield loss, with an additional 1 to $3 \%$ reduction in whole grain milling yield on 'Cocodrie', in these trials. These reductions would be very important to the economic return from a rice crop. Under current economic conditions, this loss was calculated to be over $\$ 450 /$ ha. These disease levels and yield reductions were comparable with previous studies conducted in small plots and commercial fields $(6,9,13)$.

Sheath blight was effectively controlled using azoxystrobin applied after infection at $\mathrm{PD}+7, \mathrm{~B}$, and $\mathrm{H}$ growth stages. Fungicide applied before inoculation appeared not to be as effective as fungicide applied after infection. These postinfection sprays appeared to protect uninfected tissues rather than cure already infected tissues. Preventative sprays are not recommended because of economic constraints of rice production and the fact that sheath blight does not develop to treatable levels every year. Fungicide treatment is based on scouting rice fields and applying fungicides only when treatment thresholds are exceeded. Not applying azoxystrobin represents a savings of at least $\$ 46.68 / \mathrm{ha}$ for rice producers, based on surveyed cost information. Sheath blight severity and incidence tended to be higher when fungicide applications were delayed until $\mathrm{H}$ or when fungicides were applied early at $\mathrm{PD}+7$. Boot applications in general were the best timings for sheath blight control in these studies. Less effective fungicide applications could result in the production of more inoculum in the field as infested rice stubble that could affect subsequent crops. Early applications at any rate did not lead to higher sheath blight disease levels as reported by Van Eeckhout et al. (23). Their research employed the fungicide propiconazole, which is not as effective as azoxystrobin against sheath blight and was suggested to have negative activity against antagonists on the rice plant.

Fungicide applications have been commonly used in southern Louisiana rice production $(6,9)$. In the past, two fungicide treatments were often required to effectively control sheath blight (23), but with the advent of more effective fungicides and economic constraints that limit the number of applications, a single fungicide application is now most commonly used. This study demonstrated that acceptable sheath blight control was possible with a single application of azoxystrobin made at an appropriate growth stage, no matter when the disease began to develop. Rice producers often delay fungicide application for sheath blight control until heading to also target blast. Under most conditions, this practice is justified and should provide good sheath blight control. However, delaying applications until 5 days postheading has been shown to be ineffective against sheath blight and blast (6); therefore, care must be given in monitoring rice growth stage development.

The results from this study are based on a susceptible cultivar grown in small plots. Caution generally is recommended when extrapolating small-plot data to field situations. However, trends demonstrated in small-plot research typically translate to those observed in field situations $(8,9,13)$. This is especially true when multiple tests are conducted over several years. Yield increases due to fungicide applications and levels of disease development were similar between the Rice Research Station (inoculated plots) and off-station locations (natural infestations in commercial fields) $(6,9)$. Fungicide trials conducted in commercial fields in Louisiana have produced similar results to small-plot tests (13).

This study demonstrated that rice producers can control sheath blight and improve rice yield and milling by applying azoxystrobin once at PD+7, B, or H. However, fungicide applications are not warranted if disease fails to develop. Early sheath blight development was found to be no more damaging than late-season development, which allows farmers to delay applications to more favorable timings and not suffer significant damage. However, 'Cocodrie' is not the most susceptible cultivar grown in the United States, and early sheath blight damage could be significant in more susceptible cultivars such as 'CL161'. These results are similar to those of a previous study, which demonstrated that fungicides can be applied over a range of growth stages and obtain satisfactory control (6).

\section{ACKNOWLEDGMENTS}

We thank Ray McClain and Richard Dunand for reviewing this manuscript and giving many helpful suggestions. We also thank the Louisiana Rice Research Board and Syngenta for providing support for this research and publication. We also thank Marty Frey and Joe Nugent for their hard work and assistance in conducting these studies. Approved for publication by the Director of the Louisiana Agricultural Experiment Station as manuscript number 06-61-0105.

\section{LITERATURE CITED}

1. Anonymous. 1999. Louisiana Rice Production Handbook. LSU Agricultural Center. Pub. No. 2321, Revised.

2. Bond, J. A., Walker, T. W., Bollich, P. K., Koger, C. H., and Gerard, P. 2005. Seeding rates for stale seedbed rice production in the mid-southern United States. Agron. J. 97:1560-1563.

3. Carmer, S. G., Nyquist, W. E., and Walker, W. M. 1989. Least significant differences in combined analyses of experiments with two- or three-factor treatment designs. Agron. J. 81:665-672.

4. Gangopadhyay, S., and Chakrabarti, N. K. 1982. Sheath blight of rice. Rev. Plant Pathol. 61:451-460.

5. Groth, D. E. 1996. Two new fungicides to control rice diseases. La. Agric. 39:31-33.

6. Groth, D. E. 2005. Azoxystrobin rate and timing effects on rice sheath blight incidence and severity and rice grain and milling yields. Plant Dis. 89:1171-1174.

7. Groth, D., and Lee, F. 2003. Rice diseases. Pages 413-436 in: Rice Origin, History, Technology, and Production. C. W. Smith and R. H. Dilday, eds. John Wiley \& Sons, Hoboken, NJ.

8. Groth, D. E., and Rush, M. C. 1988. New fungicides to control sheath blight of rice. La. Agric. 31:8-9.

9. Groth, D. E., Rush, M. C., Giesler, G. G., and Hollier, C. A. 1993. Foliar fungicides for use in the management of rice diseases. La. Agric. Exp. Stn. Bull. No. 840.

10. Groth, D. E., Rush, M. C., and Hollier, C. A. 1991. Rice diseases and disorders in Louisiana. La. Agric. Exp. Stn. Bull. No. 828. 37.

11. Groth, D. E., Rush, M. C., and Hollier, C. A. 1992. Prediction of rice sheath blight severity and yield loss based on early season infection. La. Agric. 35:20-23.

12. Groth, D. E., Rush, M. C., and Lindberg, G. D. 1990. Foliar fungicides for control of rice dis- 
eases in the United States. Pages 31-52 in: Pest Management in Rice. B. T. Grayson, M. B. Green, and L. G. Copping, eds. Elsevier, London.

13. Hollier, C. A., Groth, D. E., Levy, R. J., Courville, B. A., and McCorry, J. C. 1994. Rice yield differences: A comparison of fungicide application methods. Proc. Rice Tech. Wrkg. Grp. 25:88-89.

14. Jones, R. K.., Belmar, S. B., and Jeger, M. J. 1987. Evaluation of benomyl and propiconazole for controlling sheath blight of rice caused by Rhizoctonia solani. Plant Dis. 71:222-225.

15. Lee, F. N., and Rush, M. C. 1983. Rice sheath blight: A major rice disease. Plant Dis. 67:829832 .
16. Linscombe, S. D., Bollich, P. K., Groth, D. E White, L. M., and Dunand, R. T. 2000. Registration of 'Cocodrie' rice. Crop Sci. 40:294.

17. Marchetti, M. A. 1983. Potential impact of sheath blight on yield and milling quality of short statured rice lines in the southern United States. Plant Dis. 67:162-165.

18. Marchetti, M. A., and Bollich, C. N. 1991. Quantification of the relationship between sheath blight severity and yield loss in rice. Plant Dis. 75:773-775.

19. Ou, S. H. 1985. Rice Diseases. 2nd ed. Commonw. Mycological Institute, Kew, England.

20. Rush, M. C., and Lee, F. N. 1992. Sheath blight. Pages 22-23 in: Compendium of Rice Diseases. R. K. Webster and P. S. Gunnell, eds. American
Phytopathological Society, St. Paul, MN.

21. Savary, S., Willocquet, L., and Teng, P. S 1997. Modeling sheath blight epidemics on rice tillers. Agric. Syst. 55:359-384.

22. Shahjahan, A. K. M., and. Mew, T. W. 1989. Analysis of rice sheath blight (Rhizoctonia solani) development under tropical condition. Bangladesh J. Plant Pathol. 5:47-52.

23. Van Eeckhout, E., Rush, M. C., and Blackwell, M. 1991. Effects of rate and timing of fungicide applications on incidence and severity of sheath blight and grain yield of rice. Plant Dis. 75:1254-1261.

24. Zhang, W., Webster, E. P., and Leon, C. T. 2005. Response of rice cultivars to $\mathrm{V}-10029$. Weed Technol. 19:307-311. 